\title{
Т.В. Куклина
}

\section{ГОСУДАРСТВЕННАЯ НАЛОГОВАЯ ПОЛИТИКА И ЕЕ РОЛЬ В СОЦИАЛЬНО-ЭКОНОМИЧЕСКОМ РАЗВИТИИ РОССИИ}

\begin{abstract}
Статья посвящена анализу влияния направлений государственной налоговой политики на социально-экономическое развитие России за период с 1991 г. по настоящее время. Автором определены этапы в формировании государственной политики, выделенные на основе цели и ключевых задач, стоящих перед правительством страны на протяжении этого времени. В результате анализа были сформулированы ключевые направления государственной налоговой политики, актуальные для современного состояния соичильно-экономического развития России.

Ключевые слова: налоговая политика, социально-экономическое развитие, налоговый кодекс, элементы налогообложения, налоговая нагрузка, уклонение от уплать налогов, бюджет.
\end{abstract}

Налоги появляются с возникновением государственности, и факт того, что налоги являются основным источником финансирования деятельности государства, говорит о важности государственного управления налоговыми отношениями. На разных этапах исторического развития общественных отношений менялись цели и формы государственного управления налогообложением, а на определенной стадии социально-экономического развития государства выделилась особая область государственной политики - налоговая политика, направленная на регулирование социально-экономических процессов и максимальную реализацию фискальной функции налогов.

Вопросами налогообложения были озадачены еще древнейшие мыслители. Аристотель, Ксенофонт призывали государство ориентироваться не только на налоги с побежденных народов, а использовать и другие источники пополнения доходов государства [1]. В Средневековье тоже господствовала мысль о непринятии налогов как единственно возможной формы финансовой подпитки государства. Ф. Аквинский в теологических сочинениях призывал правителей вводить налоги на граждан только в период чрезвычайных ситуаций [1].

Одним из первых осмыслить налог как феномен попытался Томас Гоббс. В своем политико-философском трактате «Левиафан, или Материя, форма и власть государства церковного и гражданского» он представил первобытное общество как «войну всех против всех» [2]. Во избежание такого убийственного состояния общества была создана государственная власть. Для людей, представлявших эту власть, члены общества образовали общий фонд - государственную казну, или фиск (от лат. fiscus - казна). Следовательно, налоги были платой за общественный мир [3].

Интересно проследить роль налогов в различных направлениях экономических учений. Так, меркантилисты не ставили вопрос об абсолютном праве 
государства облагать подданных налогами, но пытались решить дилемму: какие налоги более предпочтительны - прямые или косвенные. В учении физиократов впервые была озвучена проблема справедливости налогообложения, что положило начало формированию системного знания в области налогообложения, которое было представлено классиком экономическом мысли А. Смитом. Смитом были сформулированы первые принципы налогообложения: принципы равенства, определенности, удобства, экономической обоснованности [4].

Если следовать классической экономической теории, то необходимости в формировании государственной налоговой политики нет ввиду отсутствия необходимости в государственном регулировании экономики. Известное высказывание Д. Риккардо, произнесенные в 1819 г. на заседании в палате общин: «Я враг всякого подоходного обложения. <..> Самым лучшим налогом является наименьший налог...», характеризует отношение классиков к налогообложению [3]. В классической экономической теории налоги воспринимаются как созданное государством препятствие на пути накопления первоначального капитала, но признается при этом право налогов на существование, если рассматривать их как «плату общества государству за услуги, обеспечивающие его стабильное развитие...» (Ж.-Б. Сей). Очевидно, что в рамках классической экономической школы налог не может восприниматься как инструмент регулирования экономических отношений [3].

Можно утверждать, что налоговая политика, как необходимое условие экономического развития и регулирования социально-экономических процессов, предстала в кейнсианской экономической школе. Методологический подход учения Дж. Кейнса предполагает, что экономический успех отдельно взятого хозяйствующего субъекта отнюдь не идентичен развитию экономики в целом. Между этими двумя фактами возможны противоречия, разрешение которых состоит в восстановлении пропорций в экономике и соответствия спроса и предложения. Дж. Кейнс скорректировал идеи классиков относительно саморегулируемости рыночной системы идеей того, что налоги в качестве неотъемлемого атрибута любого государства следует рассматривать как сознательно используемый регулятор нормы потребления, накопления и формирования оптимальной структуры воспроизводства [5]. Неоклассики поставили вопрос о введении налога на потребление, который представляет собой в том числе и антиинфляционный рычаг.

Известный ученый М. Фридмен - основоположник теории монетаризма придерживался идеи, что регулирование денежной массы в обращении в сочетании со снижением налогов и изменением процентной ставки позволяет обесепечить макроэкономическую и микроэкономическую стабильность [6].

В 80-е гг. была подтверждена мысль А. Смита о том, что от снижения налогового бремени на налогоплательщиков государство выигрывает больше, чем от усиления налоговой нагрузки [4]. Высокие ставки налогов, установленные, например, в США в 80-е гг., привели к росту цен, снижению эффективности производства, снижению инвестиций. Такие негативные последствия вызвала теория предложения, которая предусматривала снижение налогов и увеличение налоговых льгот (А. Лаффер) [6]. 
Налоговая политика является составляющей бюджетно-налоговой политики, которая, в свою очередь, представляет собой элемент финансовой политики. Реализация финансовой политики государства основана на законодательной базе, регулирующей финансовые отношения в государстве (законы о бюджетах разных уровней, налоговый кодекс, гражданский кодекс и т.д.), а также на институциональной базе, которую представляет система исполнительных органов власти, формирующих финансовую политику и реализующих ее.

Самая простая дефиниция налоговой политике дается Большим экономическим словарем, который определяет налоговую политику как систему мероприятий, проводимую государством в области налогов и налогообложения [7]. В данном определении нет компонента, который объединяет налоги и политику. Государственные мероприятия в области налогов и налогообложения будут иметь характер налоговой политики тогда, когда они будут проводиться во взаимной увязке интересов государства и общества в соответствии с принципами налогообложения и реализовываться для достижения социально-экономических целей, соответствующих данному этапу исторического развития страны. В этой связи можно привести в качестве примеров следующие определения налоговой политики:

- определение Н.Г. Лукьяновой : «Налоговая политика - это часть экономической политики государства, представляющая собой комплекс мероприятий по совершенствованию налоговой системы страны на основе стратегической концепции развития налоговой системы» [8];

- определение В.Г. Князева: «Налоговая политика - это составная часть экономической политики, направленная на формирование налоговой системы, обеспечивающей экономический рост, способствующей гармонизации экономических интересов государства и налогоплательщиков с учетом социально-экономической ситуации в стране» [9].

И первый и второй подход к раскрытию сущности налоговой политики определяют важную роль налоговой политики в социально-экономическом развитии государства и особое ее значение в достижении экономического роста.

Целью настоящего исследования является обзор направлений государственной налоговой политики за период 1991-2013 гг. и анализ их влияния на социально-экономическое развитие России. При исследовании использовались общелогические методы: анализ, синтез, обобщение, а также метод системного подхода.

В России с началом рыночных преобразований в конце 80-х гг. XX в. появилась необходимость в создании налоговой системы, отвечающей потребностям государства с рыночной экономикой. Началом формирования российской налоговой системы в новых условиях хозяйствования стало принятие закона Российской Федерации от 27.12.1991 г. «Об основах налоговой системы». В этом же году была учреждена Государственная налоговая служба как орган, на которого возлагалась обязанность по контролю за соблюдением налогового законодательства. Если проанализировать проводимую государственную налоговую политику в период с 1991 г. по настоящее время, 
то можно отметить следующие этапы с точки зрения приоритетных задач, стоящих перед государством при формировании налоговой политики:

1. 1991-2000 гг.

2. 2001-2005 гг.

3. 2006-2008 гг.

4. Конец 2008-2010 гг.

5. 2011 г. - настоящее время.

\section{Государственная налоговая политика в период 1991-2000 z2.}

Главной задачей этого этапа развития российской налоговой системы являлось создание правовых, экономических и институциональных основ функционирования налоговой системы. В этот период времени как таковой государственной налоговой политики не проводилось, учитывая тот факт, что в условиях отсутствия, по сути, налогового законодательства и институтов сложно было реализовывать регулирующую составляющую налогов. Большое влияние на формирование налоговой системы того времени оказывал тяжелый и затяжной экономический кризис, который сгенерировал социальный кризис, выразившийся в утрате доверия населения к правительству и проводимым реформам. Эти моменты не могли не сказаться на процессе формирования налоговой системы страны, поскольку для успешной реализации государственной налоговой политики важное значение имеет отношение населения к государству и процессу уплаты налогов. Характерным был крен в сторону гипертрофированного усиления фискальной функции, так как в условиях бюджетного дефицита, падения объемов производства, высокой инфляции велик был соблазн все экономические проблемы государства решить через налоги [10]. В силу этого возникло чрезмерное количество налогов, были установлены завышенные ставки, что повлекло появление доселе неизвестного в Росси феномена - уклонения от уплаты налогов.

Налоговая система начала 90-х гг. по форме во многом соответствовала налоговым системам зарубежных стран. Однако при введении перечня налогов не были учтены особенности переходного периода, который переживала экономика России. Новые налоги оказались тяжелым бременем для предприятий, положение которых и без того было подорвано непродуманными мерами в области политики цен и приватизации.

Особенности функционирования налоговой системы в 90-е гг. не оставляли возможностей для качественного финансового планирования на макро-, мезо- и микроуровне даже на короткий период времени. В ситуации, когда государство было неспособно обеспечить тотальный контроль за уплатой налогов всеми субъектами хозяйственной деятельности, в полном объеме налоги платили только добросовестные налогоплательщики, не имеющие льгот и недоимок. Для них налоговое бремя оказалось чрезмерно высоким, и в результате они либо выталкивались с рынка, либо начинали уклоняться от налогов.

Налоговая система того времени спровоцировала появление таких проблем, как развитие теневой экономики, бегство капитала за границу, формирование отрицательного инвестиционного климата в стране и, как следствие, снижение темпов экономического роста. 


\section{Государственная налоговая политика в период 2001-2005 22.}

К 2001 г. российская экономика подошла с показателями социальноэкономического развития и развития налоговой системы, представленными в табл. 1 [11].

Таблица 1

Некоторые показатели экономического развития России в 1998-2001 гг.

\begin{tabular}{|c|c|c|c|c|}
\hline Показатели & 1998 & 1999 & 2000 & 2001 \\
\hline ВВП, млрд руб. & 2629,6 & 4823,2 & 7305,6 & 8943,6 \\
\hline $\begin{array}{l}\text { Темпы } \\
\text { роста, \% } \\
\text { году }\end{array}$ & 94,7 & 106,4 & 110,0 & 105,1 \\
\hline 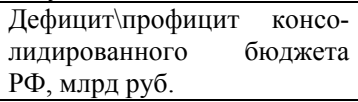 & $-155,3$ & $-44,4$ & 137,6 & 264,3 \\
\hline Налоговая нагрузка, \% & & & & \\
\hline $\begin{array}{l}\text { Количество налогов в нало- } \\
\text { говой системе }\end{array}$ & & & & \\
\hline $\begin{array}{l}\text { Задолженность по налогам и } \\
\text { сборам, млрд руб. }\end{array}$ & 181,8 & 259 & 371,6 & 461,7 \\
\hline $\begin{array}{l}\text { Удельный вес } \text { убыточных } \\
\text { организаций, \% }\end{array}$ & 53,2 & 40,8 & 39,8 & 37,9 \\
\hline
\end{tabular}

Данные таблицы свидетельствуют об улучшении макроэкономических показателей к 2001 г. Главным результатом проводимой работы Правительства РФ по восстановлению экономики России в посткризисный период стал профицит консолидированного бюджета РФ. Также к 2001 г. Россия стала демонстрировать достаточно высокие темпы экономического роста. Отрицательным моментом являлось низкое качество экономического роста, так как основным фактором улучшения экономической ситуации стал не внутренний потенциал государства, а установление к 2000 г. благоприятной конъюнктуры на рынке нефти. Именно данный фактор повлиял на формирование профицитного консолидированного бюджета впервые за годы рыночных преобразований.

Налоговая система России на тот момент характеризовалась достаточно высокой налоговой нагрузкой, в особенности на предприятия промышленной сферы. В налоговой системе отсутствовал регулирующий механизм, в частности, отсутствовал механизм стимулирования малого бизнеса, инвестиционной деятельности. Большое количество налоговых платежей, высокая налоговая нагрузка, запутанность налогового законодательства, неэффективная работа налоговых органов провоцировали массовое уклонение от уплаты налогов и рост задолженности по налогам и сборам в бюджетную систему (табл. 1).

Данные проблемы, вызванные проводимой налоговой реформой, потребовали от правительства существенной корректировки налоговой системы и выявили основную задачу в области налоговой политики на предстоящий период - снижение налоговой нагрузки и упрощение налоговой системы.

Надо отметить, что период 2001-2005 гг. был одним из самых продуктивных с точки зрения законодательного аспекта и положительных для российских налогоплательщиков. Основным результатом данного периода стало 
снижение совокупной налоговой нагрузки до 27\% к 2005 г., по данным ФНС России. Факторы уменьшения налогового бремени [10]:

1. Сокращение общего количества налогов и сборов с 54 до 15\% к 2005 г.

2. Введение специальных налоговых режимов для предприятий малого бизнеса и сельскохозяйственных предприятий.

3. Снижение нагрузки на фонд оплаты труда. Ставка ЕСН была снижена до $26 \%$.

4. Снижение налоговых ставок по налогу на прибыль с 35 до $24 \%$.

5. Переход к плоской шкале НДФЛ - 13\%.

6. Снижение налоговой ставки по НДС с 20 до 18\%.

Вместе с тем по-прежнему в налоговой системе оставались нерешенными многие вопросы. Одной из значимых проблем являлось низкое качество работы налоговых органов. Изначально налоговые органы для российских налогоплательщиков предстали в образе карательного ведомства, не желающего формировать партнерские отношения с налогоплательщиками. В силу недостатка квалификации, высокой загруженности налоговых инспекторов и низкой степени автоматизации их функций такая форма взаимодействия, как консультирование налогоплательщиков по вопросам неясности налогового законодательства, оставалась нереализованной в полной мере. Кроме того, налогоплательщики испытывали явные неудобства при взаимодействии с налоговыми органами при сдаче налоговой отчетности и прохождении процедуры регистрации ввиду наличия больших очередей в налоговых инспекциях. Оставляло желать лучшего и качество проводимых контрольных мероприятий, в особенности выездных налоговых проверок.

Несмотря на совокупное снижение налоговой нагрузки, одной из проблем налоговой системы того времени являлось отсутствие в налоговом законодательстве мер стимулирования инновационной деятельности за счет предоставления предприятиям, осуществляющим вложения в НИОКР, налоговых преференций.

Оставалась также нерешенной проблема уклонения от уплаты налогов. Например, главной целью снижения совокупной ставки по ЕСН являлась легализация теневой заработной платы, однако в реальности массового выведения заработных плат из тени не произошло и назрела угроза дефицитности внебюджетных фондов. Многие налогоплательщики использовали в своей практике схемы минимизации налога на прибыль, НДС, налога на имущество организаций с помощью фирм-однодневок и офшоров. Налоговые органы часто оказывались не способны доказать факт незаконной минимизации налогов в силу отсутствия четкости и ясности в понятийном аппарате налогового производства. Именно по этой причине большинство налоговых споров в суде выигрывали налогоплательщики из-за несовершенства налогового законодательства и недостатка необходимого инструментария для доказательства применения налогоплательщиками схем минимизации налогов.

Поскольку задача по снижению налоговой нагрузки была выполнена и дальнейшее снижение налогового бремени ставило бы вопрос о финансовой устойчивости бюджетной системы, то первоочередной задачей на следующие годы стало совершенствование налогового администрирования. 


\section{Характеристика и итоги реализации государственной налоговой по- литики в 2006-2008 z2.}

Основная задача данного этапа - создание условий для стимулирования инновационной деятельности и совершенствование налогового администрирования. С этого периода российские ученые и специалисты в области налогообложения стали активно исследовать теоретико-методологические аспекты налогового администрирования и направления его улучшения. Ориентируясь на зарубежный опыт, Минфином совместно с ФНС были выработаны основные направления совершенствования налогового администрирования в России, которые нашли отражение в Федеральном законе «О внесении изменений в часть первую и часть вторую Налогового кодекса Российской Федерации и в отдельные законодательные акты Российской Федерации в связи с осуществлением мер по совершенствованию налогового администрирования» от 27.07.2006 г.

С принятием данного закона начался новый виток налоговой реформы в России, направленный на совершенствование функций налоговых органов, а также на упрощение и облегчение налоговых процедур. Задача по совершенствованию налогового администрирования будет поставлена и в последующие периоды, но именно на данном этапе в первую часть Налогового кодекса были внесены наиболее существенные изменения.

Благоприятная экономическая ситуация, которая сложилась в России к 2006 г., способствовала возможности внедрения среднесрочного бюджетного планирования, что свидетельствовало о наступлении экономической и финансовой стабильности в государстве. Внедрение данного инструмента в сильной мере оказало влияние на формирование налоговой политики. Успешная и грамотная разработка трехлетнего бюджетного плана требует стабильности и упорядоченности налогового законодательства и налоговой политики, поскольку налоговые доходы являются определяющими при создании бюджетного плана и определении направлений и величины бюджетных расходов. В этой связи в 2006 г. Минфином впервые был разработан документ «Об основных направлениях налоговой политики на 2007-2009 годы». Документ включал в себя анализ текущей ситуации и задачи по совершенствованию налоговой системы в 2007-2009 гг. В данном документе прослеживалось осуществление налоговой политики в среднесрочном периоде по двум направлениям:

1) повышение качества налогового администрирования;

2) совершенствование порядка исчисления и администрирования некоторых налогов (в частности, в 2006-2007 гг. ставилась задача по совершенствованию налога на прибыль, налога на добычу полезных ископаемых, НДС).

Основными результатами проводимой налоговой политики на данном этапе стали:

1. Совершенствование первой части Налогового кодекса, направленное на урегулирование наиболее спорных моментов при проведении налогового контроля. В 2006 г. было внесено множество изменений, направленных на обеспечение оптимального баланса прав и обязанностей налогоплательщиков и налоговых органов. В основном изменения касались урегулирования спорных ситуаций, а также ухудшающих положение налогоплательщика при про- 
ведении налогового контроля (ограничение сроков проведения выездных налоговых проверок, жесткая регламентация возможности, оснований и сроков приостановления выездной налоговой проверки). При этом некоторые замыслы, призванные улучшить положение налогоплательщиков, оказались неработающими в реальной действительности. Так, например, изменениями устанавливались ограничения по истребованию налоговыми органами первичных документов при проведении проверок, но это право сохраняется в ряде случаев, которые как раз и являли собой типичные ситуации.

Были утверждены критерии оценки деятельности налоговых органов, которые учитывают не только эффективность мероприятий по контролю за соблюдением налогового законодательства, но и состояние работы с налогоплательщиками в целом. Анализ результатов в соответствии с этими критериями позволит более точно оценить результативность работы налоговых органов, в том числе и в отношении налогов, поступающих в бюджеты субъектов и местные бюджеты. На основании этих критериев утверждена и начала применяться система премирования сотрудников налоговых органов в зависимости от достигнутых результатов.

Также в налоговых органах была создана система внутреннего налогового аудита. Подход, основанный на разделении функций по принятию решений по результатам налоговых проверок, выполняемых контрольными подразделениями Федеральной налоговой службы, и рассмотрению жалоб налогоплательщиков на указанные решения, оправдывает себя. Изменение подходов к организации налогового контроля, а также усиление аналитической составляющей в деятельности Федеральной налоговой службы приводят к заметному сокращению количества выездных налоговых проверок. Так, если в 2004 г. было проведено 306 тыс. выездных налоговых проверок, то по итогам 2007 г. их количество составило 106 тыс. С 56 тыс. в 2006 г. до 17 тыс. в 2007 г. сократилось количество «тематических проверок», что свидетельствует о комплексном подходе налоговых органов к организации проверки, а также приводит к снижению административной нагрузки на бизнес [12].

На данном этапе была начата работа по внедрению процедуры досудебного урегулирования налоговых споров, которая была окончательно введена с 01.01.2009 г., основной целью ее являлось сокращение судебной нагрузки.

Несмотря на принятые изменения, и бизнес сообществом, и государственными деятелями, и экспертами признавалось, что налоговое администрирование все еще нуждается в серьезном изменении ввиду нерешенности многих вопросов. В особенности проблем контроля за применением налоговых схем. В этот период осуществлялась разработка законопроектов, направленных на совершенствование контроля за трансфертным ценообразованием и введением института консолидированных групп налогоплательщиков. Скорому принятию данных законопроектов помешал финансовый кризис, разразившийся в России в середине 2008 г., в связи чем были смещены ориентиры государственной налоговой политики с совершенствования налогового администрирования на снижение налоговой нагрузки экономических субъектов с целью минимизации финансовых потерь в связи с кризисной ситуацией. 


\section{Итоги реализации государственной налоговой политики с конца 2008 no 2010 z.}

На данном этапе государственная налоговая политика носила антикризисный характер и проводилась в соответствии с Программой антикризисных мер Правительства РФ, разработанной в 2009 г. и включающей налоговый компонент.

Мировой финансовый кризис, неблагоприятно отразившийся на работе хозяйствующих субъектов и финансовом положении домашних хозяйств, потребовал от правительства создания мер антикризисного характера, направленных на поддержание ликвидности и финансовой устойчивости предприятий и обеспечение финансового благосостояния граждан. Наиболее значимым событием в данный период явилось снижение налоговой ставки с 24 до 20\%, что было вызвано также проводимой антикризисной программой правительства. Вместе с тем данную меру назвать эффективной антикризисной мерой нельзя, поскольку за 2008 г. убыточные налоговые декларации показали большинство налогоплательщиков в рамках общего режима налогообложения, ввиду чего снижение налоговой ставки при этом не оказывало на них никакого влияния, поскольку налог вообще не уплачивается в этой ситуации.

Снижение реальных доходов граждан в период кризиса потребовало также введения комплекса мер по снижению налоговой нагрузки на физические лица. В силу этого были увеличены социальные и имущественные налоговые вычеты по налогу на доходы физических лиц.

По НДС был увеличен налоговый период, который стал составлять один квартал для всех налогоплательщиков. Кроме того, начиная с четвертого квартала 2008 г. суммы налога, исчисленные налогоплательщиками по операциям по реализации товаров (работ, услуг), признаваемых объектом налогообложения этим налогом, стали уплачиваться в бюджет равными долями не позднее 20-го числа каждого из трех месяцев, следующих за истекшим кварталом, т.е. фактическая уплата налога стала производиться не единовременно до 20-го числа месяца, следующего за истекшим налоговым периодом, как это было предусмотрено ранее, а ежемесячно в размере $1 / 3$ в течение трех последующих месяцев. Данный порядок уплаты налога позволил снизить текущий дефицит оборотных средств и стабилизировать деятельность налогоплательщиков. Был увеличен до 270 дней срок сбора документов, обосновывающих правомерность применения нулевой ставки. Также было введено изменение в порядок проведения камеральных проверок по НДС: по результатам налоговой проверки одной декларации налоговые органы вправе выносить два решения: одно - в отношении сумм, правомерность принятия которых к вычету документально подтверждена, второе - в отношении сумм, по которым необходимо представление дополнительных обосновывающих материалов. Это позволяет налогоплательщикам возместить из бюджета часть суммы, в отношении которой налоговые органы не имеют возражений. В среднем это позволило сократить сроки возмещения налога на добавленную стоимость в спорных случаях на 2-3 месяца по сравнению с ранее действовавшим порядком. 
Кроме того, в данный период были внесены такие изменения, как: разрешение списывать расходы на НИОКР в течение одного года независимо от их результата, разрешение списывать убытки прошлых лет в полном размере в течение года.

Как мера, генерирующая повышение качества добычи полезных ископаемых, был установлен понижающий коэффициент, стимулирующий дальнейшую разработку нефтяных месторождений, - для месторождений, находящихся на завершающей стадии разработки; введение нулевой налоговой ставки по налогу на добычу полезных ископаемых для новых нефтяных месторождений, расположенных в Восточно-Сибирской нефтегазовой провинции, и продление действия до 2017 г. специфической ставки налога на добычу полезных ископаемых по нефти, «привязанной» к мировым ценам на этот товар.

Финансовый кризис обнажил проблемы бюджетной несбалансированности и сильной привязанности к сырьевому фактору. Повышение удельного веса нефтегазовых доходов в доходной части федерального бюджета продемонстрировало низкую собираемость других налогов, не зависящих от внешних факторов, таких как цены на экспортируемое сырье. В силу этого, в последующие этапы налоговая политика стала формироваться исходя из главной задачи - достижения сбалансированности бюджетной системы за счет совершенствования налогового администрирования.

\section{Реализация налоговой политики в период 2011 г. по настоящее время}

Одним из самых негативных моментов, наблюдающихся в российской экономике, является дефицит федерального бюджета, в силу чего происходит сокращение расходов почти по всем направлениям. Налоги служат основным источником доходной базы бюджета, и в связи с этим важнейшим фактором проводимой посткризисной налоговой политики является необходимость поддержания сбалансированности бюджетной системы.

Основными результатами проводимой налоговой политики в период 2010-2013 гг. стали:

1. Совершенствование налогового администрирования в части налогового контроля за трансфертным ценообразованием и введения института консолидированного налогоплательщика.

В соответствии с п. 1 ст. 25.1 НК РФ консолидированная группа налогоплательщиков (КГН) - добровольное объединение плательщиков налога на прибыль организаций на основе договора о создании консолидированной группы налогоплательщиков в порядке и на условиях, которые предусмотрены НК РФ, в целях исчисления и уплаты налога на прибыль организаций с учетом совокупного финансового результата хозяйственной деятельности данных налогоплательщиков. Это новшество приносит два преимущества налогоплательщикам. Во-первых, учитывая, что в результате суммирования полученных доходов и расходов всех участников группы в полученном результате уже будут учтены полученные убытки в отношении одной или нескольких организаций, входящих в состав группы, то при создании консолидированной группы налогоплательщиков могут быть оптимизированы суммы налога на прибыль, подлежащие уплате в бюджет. Во-вторых, участники 
консолидированной группы налогоплательщиков не представляют налоговые декларации в налоговые органы по месту своего учета, если не получают доходов, не включаемых в консолидированную налоговую базу этой группы. К таким доходам относятся доходы, облагаемые по иным ставкам, либо доходы в случае удержания и уплаты налога на прибыль у источника выплаты. Условия, предъявляемые для создания группы и участия в ней, в настоящее время довольно жесткие, ввиду чего на 01.01.2013 г., по данным ФНС России, в налоговых органах зарегистрировано 15 консолидированных групп налогоплательщиков. В основном объединение крупных налогоплательщиков в группы произошло в нефтегазовом секторе, металлургии и связи. Расчеты, произведенные ФНС России на основании данных, представленных налогоплательщиками, в условиях создания консолидированных групп налогоплательщиков и без учета объединения организаций в консолидированные группы, показали, что функционирование КГН привело к росту поступлений налога на прибыль организаций в размере 53 млрд руб. в 78\% субъектов Российской Федерации. Поступления в консолидированные бюджеты субъектов Российской Федерации в результате создания КГН снизились на 8 млрд руб. [21].

C 1 января 2012 г. вступил в силу раздел $\mathrm{V}^{1}$ Налогового кодекса, которым установлены принципы определения цен для целей налогообложения в связи с совершением сделок между взаимозависимыми лицами. Положения указанного раздела направлены на предотвращение вывода налоговой базы за пределы РФ, обеспечение справедливого и экономически обоснованного распределения налоговой базы между субъектами Российской Федерации, а также на исключение возможностей получения необоснованной налоговой выгоды в результате манипулирования ценами в сделках между налогоплательщиками, применяющими различные режимы налогообложения внутри страны. Необходимость этих нововведений, как и в иных государствах, осуществляющих налоговый контроль в связи с совершением сделок между взаимозависимыми лицами, обусловлена растущей глобализацией бизнеса, возможностью по-разному структурировать сложные сделки, используя нематериальные активы и финансовые инструменты в различных юрисдикциях.

2. Устранение двойного налогообложения имущества юридических лиц, за счет того, что транспортные средства, введенные в эксплуатацию организацией с 1 января 2013 г., перестали облагаться данным налогом.

3. Введение изменений в налоговое законодательство, направленных на повышение налоговых доходов в бюджет за счет:

- установления дополнительной фискальной нагрузки на газовую отрасль путем ежегодного увеличения, начиная с 2013 г., и дифференциации ставки налога на добычу полезных ископаемых, взимаемого при добыче газа горючего природного;

- индексации ставок акцизов;

- увеличения налоговой нагрузки на владельцев предметов роскоши. Так, повышенные налоговые ставки предусматриваются в отношении объектов недвижимости, кадастровая стоимость которых превышает 300 млн руб. Также произошло увеличение ставок транспортного налога по автомобилям, имеющим высокую мощность двигателя; 
- сокращения налоговых льгот. По результатам проведенной в 2010 2012 гг. инвентаризации налоговых льгот по региональным и местным налогам в целях децентрализации полномочий между уровнями публичной власти в пользу субъектов Российской Федерации и местного самоуправления принят Федеральный закон от 29 ноября 2012 г. № 202-Ф3, предусматривающий поэтапную отмену начиная с 2013 г. наиболее крупных налоговых льгот; по налогу на имущество организаций в отношении железнодорожных путей общего пользования, магистральных трубопроводов, линий энергопередачи, сооружений, являющихся их неотъемлемой технологической частью, с постепенным увеличением ставки с 0,4\% в 2013 г. до 2,2\% в 2019 г.

4. Введение изменений в порядок применения специальных налоговых режимов. С 2011 г. осуществляется деятельность по разработке и принятию законопроекта о введении нового специального налогового режима - патентная система налогообложения, который до 2018 г. полностью заменил действующую систему налогообложения в виде единого налога на вмененный доход. Патентная система налогообложения применяется по 47 видам деятельности, перечисленным в Налоговом кодексе. Данный режим упрощает взаимодействие налогоплательщика с налоговыми органами, но имеет также и недостатки, связанные с возможным увеличением налоговой нагрузки в сравнении с применением ЕНВД, поскольку при применении первого не допускается уменьшать сумму налога на величину уплачиваемых страховых взносов во внебюджетные фонды.

Проанализировав эволюцию налоговой политики на протяжении 19912013 гг., определим основные недостатки и необходимые направления развития государственной политики в области налогообложения для социальноэкономического развития России в последующие периоды:

1. Недостаточное использование возможностей налоговой политики в части стимулирования инноваций. Выражение «экономика, основанная на знаниях» призвано подчеркнуть движение высокоразвитых экономик к большей зависимости от знаний, информации, высокой квалификации и нарастающую потребность предпринимательского и общественного (государственного) секторов экономики в легком доступе ко всему перечисленному.

Модернизацию экономики часто отождествляют с инновационным развитием страны. Инфраструктура российской экономики уже не соответствует современным требованиям и тенденциям развития экономики. Объяснением этому является затяжной кризис 90-х гг., решение ряда неотложных задач на протяжении 2000-х гг., наличие богатых запасов природных ресурсов, что изначально создает соблазн ориентироваться прежде всего на добычу и продажу полезных ископаемых, минуя трудности развития обрабатывающих отраслей и создания инновационной сферы.

Согласно статистическим данным, степень износа основных фондов увеличилась в РФ с 39,3\% в 2000 г. до 47,7\% в 2012-м. В отдельных системах показатель износа значительно больше [25]:

- транспорт и связь $-56,2 \%$;

- добыча полезных ископаемых - 51,2\% ;

- здравоохранение - 52,7\%;

- строительство - 49\%; 
- обрабатывающие производства - 46,8\%.

Степень износа основных фондов в целом по экономике и по видам экономической деятельности имеет тенденцию к росту. Доля инновационной продукции в промышленном производстве России находится на уровне 5,5\%. В США она составляет 70 \%, в Китае приближается к $34 \%$ [26]. В 2009 г. разработку и внедрение технологических инноваций осуществляли 9,4\% общего количества предприятий российской промышленности. Это значительно ниже, чем [11]:

- в Германии $-71,8 \%$;

- в Бельгии - 53,6\%;

- в Эстонии - 52,8\%;

- в Финляндии - $52,5 \%$;

- в Швеции - 49,6\%.

Государство может стимулировать развитие инноваций при помощи:

1) прямых государственных субсидий инновационным предприятиям;

2) субсидирования при уплате процентов по долгосрочных кредитам, полученным в рамках инновационных проектов;

3) налоговых льгот.

Все эти инструменты используют правительства иностранных государств с целью стимулирования инновационного развития экономики. В таких странах, как Германия, Канада, Япония, Китай, основная доля государственного участия принадлежит косвенным инструментам стимулирования инноваций в форме предоставления налоговых льгот предприятиям, имеющим статус инновационных. В российском налоговом законодательстве существует ряд мер, направленных на стимулирование инноваций, но пока они не приносят должного результата в силу их явно неоднозначного эффекта на деятельности организаций:

- сокращен до 1 года срок принятия к вычету расходов на НИОКР независимо от результата для целей налогообложения прибыли;

- увеличен до 1,5\% от выручки (втрое по сравнению с действовавшим ранее) норматив расходов на НИОКР, осуществляемых в форме отчислений на формирование Российского фонда технологического развития и других отраслевых фондов;

- введен повышающий коэффициент 1,5, позволяющий учесть в расходах по налогу на прибыль организаций больше затрат на НИОКР в сравнении с фактическим затратами, по более чем 120 направлениям;

- введена амортизационная премия;

- предоставлена возможность применения нелинейного (ускоренного) метода начисления амортизации, позволяющего отнести на расходы до $50 \%$ первоначальной стоимости основных средств в течение первой четверти срока их полезного использования;

- введены льготы по НДС, налогу на прибыль организаций, налогу на имущество организаций, земельному налогу и страховым взносам для резидентов особых экономических зон;

- имеется возможность применения инвестиционного налогового кредита, в том числе при проведении НИОКР, технического перевооружения, осуществлении внедренческой или инновационной деятельности; расширены 
условия для принятия в расходы затрат на профессиональную подготовку и переподготовку работников.

Вместе с тем, если проанализировать статистические данные, то приходим к выводу, что:

1) инновационная активность предприятий не возрастает значительно, что подтверждается данными табл. 2.

Таблича 2

Инновационная активность организаций (удельный вес организаций, осуществлявших технологические, организационные, маркетинговые инновации в отчетном году, в общем числе обследованных организаций) по видам экономической деятельности [11]

\begin{tabular}{l|c|c|c|c}
\hline \multicolumn{1}{c|}{ Виды экономической деятельности } & 2009 & 2010 & 2011 & 2012 \\
\hline Всего & 9,3 & 9,5 & 10,4 & 10,3 \\
\hline Добыча полезных ископаемых & 7,2 & 7,8 & 8,4 & 8,2 \\
\hline Обрабатывающие производства & 13,3 & 13,0 & 13,3 & 13,4 \\
\hline $\begin{array}{l}\text { Производство и распределение электроэнергии, газа } \\
\text { и воды }\end{array}$ & 5,4 & 5,4 & 5,6 & 5,6 \\
\hline Связь & 15,1 & 15,6 & 13,8 & 13,3 \\
\hline $\begin{array}{l}\text { Деятельность, связанная с использованием вычисли- } \\
\text { тельной техники и информационных технологий }\end{array}$ & 9,5 & 10,0 & 9,2 & 9,4 \\
\hline
\end{tabular}

Динамика инвестиционной активности хоть и положительна, но процесс идет крайне медленно;

2) процедура предоставления инвестиционного налогового кредита является достаточно сложной и неперспективной, ввиду чего, например, в 2013 г. инвестиционный налоговый кредит был предоставлен только в двух субъектах РФ: Республике Коми (по региональным налогам) и Ханты-Мансийском автономном округе (по федеральным налогам и сборам) [27];

3) отсутствуют налоговые механизмы стимулирования потребления инновационных продуктов;

4) наиболее существенные льготы предоставляются организациям, только если они являются резидентами особых экономических зон (ОЭЗ), т.е. практически эти льготы носят точечный локальный характер.

2. Российская налоговая политика демонстрирует слабую реализацию социиальной функичи.. Одним из главных правил здоровой налоговой политики является распределение основной массы налогового бремени, основанное на принципе социальной справедливости. Принцип социальной справедливости раскрывается при налогообложении сферы потребления и доходов. При налогообложении сферы потребления принцип социальной справедливости выражается в льготном налогообложении товаров, продуктов и услуг, входящих в состав необходимого минимума потребления (продукты питания, одежда, обувь, товары для детей, коммунальные услуги, связь и транспорт и др.). На первый взгляд принцип социальной справедливости в данном аспекте в российской налоговой системе реализуется посредством введения пониженной ставки НДС в размере $10 \%$ по товарам первой необходимости и освобождения от налогообложения НДС реализации некоторых товаров и услуг, которые также являются необходимыми для поддержания нормального жизнеобеспечения граждан. Но важная особенность российской налоговой политики заключается в чрезмерно высокой доле косвенных налогов. По потреби- 
тельским товарам реальными плательщиками этих налогов выступают физические лица, в связи с чем существенно снижается жизненный уровень малообеспеченных.

При налогообложении доходов принцип социальной справедливости выражается в прогрессивном налогообложении доходов физических лиц. Плоская шкала НДФЛ является достаточно редким явлением в мировой налоговой системе и не характерна для развитых стран. Как пример, плоская шкала о НДФЛ действует в Венгрии, в странах Прибалтики, некоторые небольших представителях третьего мира и офшорах. Словакия также имела плоскую шкалу, однако ввела прогрессивный налог с 2013 г. В 2001 г.: 13\% вместо прогрессивной 12-30\%. В первый же год, когда была введена плоская шкала НДФЛ, реальные доходы (за вычетом инфляции) бюджета выросли на 26\%, на следующий год - еще на $25 \%$, на третий - на $15 \%$. Основываясь на этих данных, МВФ ссылается на Россию как на самый удачный пример перехода к плоской шкале. Переход к плоской шкале в других странах не показал такого значительного успеха, но объясняется это тем, что в России в качестве единой ставки была нижняя граница прогрессивной шкалы, в то время как в других странах плоская шкала оказалась близка к ее верхним значениям. В России от введения плоской школы выиграли высокодоходные слои населения, а малообеспеченные при этом не ощутили положительных или отрицательных последствий реформы. Приняв плоскую шкалу налогообложения и создав благоприятные условия налогообложения доходов высокообеспеченных слоев населения, Правительство РФ сделало жест, означающий отказ от борьбы с социальным неравенством, а ведь это одна из острейших проблем социального развития России в перестроечный и постперестроечный периоды. Неравенство в России очень заметное и продолжает усиливаться. Коэффициент Джини, отражающий неравенство в доходах, вырос с 0,26 в 1991 г. до 0,42 в 2012-м [28].

На наш взгляд, учитывая данный фактор, а также неблагоприятную ситуацию в бюджетной системе РФ, в России налоговая политика должна формироваться в интересах соблюдения принципа социальной справедливости и тем самым должна быть направлена на введение прогрессивного налогообложения доходов физических лиц. Введение прогрессивной шалы НДФЛ позволило бы сделать систему стандартных налоговых вычетов более продуктивной для российских налогоплательщиков, имеющих невысокие доходы. Стандартный налоговый вычет, который сегодня предоставляет налогоплательщикам пособие на первого ребенка в размере 1400 руб. и 3000 руб. на второго и каждого последующего, явно не оказывает стимулирующего воздействия на повышение рождаемости и не облегчает тяжесть налоговой нагрузки на малообеспеченные слои населения, имеющие на иждивении детей.

3. Неоднозначность результатов налоговой политики. По мнению чиновников, главным результатом налоговой политики последних лет следует считать уменьшение совокупной налоговой нагрузки, особенно если сравнивать совокупную налоговую нагрузку в России и в развитых странах. Но нужно учитывать, что налоговая нагрузка в развитых странах серьезно дифференцирована по категориям налогоплательщиков в части прямого налогообложения. Кроме того, в последние годы в России наблюдается тенденция к 
уменьшению количества налогов и сборов, а также замене системы налоговых (обязательных) платежей на неналоговые, соответственно на последние смещается и налоговая нагрузка. Ярким примером является замена ЕCH, продемонстрировавшего достаточно высокую эффективность, на социальные взносы, что повлекло за собой значительные дополнительные расходы на налоговое администрирование. В результате фискальное бремя в целом увеличивается, но официально декларируемая налоговая нагрузка при этом остается неизменной или даже уменьшается [29].

4.Игнорирование объективной необходимости в повышении налоговой нагрузки для некоторых экономических агентов с иелью снижения финансовой напряженности в бюджетной системе РФ. В документе «Об основных направлениях налоговой политики на 2014 год и плановый период 20152016 годы» указано в качестве результатов налоговой политики в прошедшие периоды принятие мер, направленных на увеличение доходной базы бюджетов. Но данные меры явно не приведут к существенному сокращению дефицита федерального бюджета.

Главной дилеммой национальной налоговой политики в современных условиях, таким образом, становится противоречие между необходимостью поддержания умеренного характера налогообложения для стимулирования посткризисного роста экономики, инновационной активности, высокого уровня потребления и сбережений хозяйствующих субъектов и объективными потребностями в повышении налогов для решения проблем в сфере государственных финансов и реализации принципа социальной справедливости в распределении доходов [30].

Необходимость повышения уровня налогообложения связана со следующими особенностями текущего развития системы мирохозяйственных связей:

- дефицитом федерального бюджета и государственных внебюджетных фондов;

- усилением дифференциации в распределении доходов;

- снижением рождаемости и старением населения.

5. Необходимость в совершенствовании работы налоговых органов и внедрении новейших методов налогового администрирования, позволяющих уменьшать налоговые злоупотребления и способствующих легализаџии российской экономики. Последний пункт является крайне важным в условиях реализации всех вышеперечисленных направлений государственной налоговой политики. Уклонение от уплаты налогов, минимизация налоговых платежей - закономерная реакция налогоплательщиков на повышение налогового бремени. В силу этого, успешная реализация налоговой политики требует повышения качества работы налоговых органов, совершенствования налогового администрирования.

На наш взгляд, подобные мероприятия налоговой политики согласуются с общемировыми тенденциями развития налоговых систем в рамках преодоления последствий мирового финансового кризиса и неблагоприятного его влияния на финансовую устойчивость бюджетных систем развитых стран мира. 


\section{Литература}

1. Азаркин Н.Н., Левченко В.Н., Мартышкин О.В. История политических учений: Вып. 1 М.: Юрист, 1996. 140 с.

2. Гоббс T. Левиафан, или Материя, форма и власть государства церковного и гражданского. М.: Мысль, 2001. 478 с.

3. Пушкарева В.М. История финансовой мысли и политики налогов. М.: Финансы и статистика, 2008. $252 \mathrm{c.}$

4. Смит А. Исследование о природе и причинах богатства народов. М.: Соцэкизд., 1962.

5. Кейнс Дж.М. Общая теория занятости, процента и денег. М.: Прогресс, 1992.

6. Лях О.А., Гринкевич Л.С. Региональная налоговая политика: сущность, направления совершенствования. Томск: Изд-во НТЛ, 2010. 240 с.

7. Борисов А.Б. Большой экономический словарь. М.: Книжный мир, 2007. 860 с.

8. Лукьянова Н.Г. Управление налоговой системой государства: систематизация понятийного аппарата // Финансовый мир. 2002. Вып. 1.

9. Черник Д.Г. Налоги и налогообложение. М.: ИНФРА-М, 2001. 574 с.

10. Аронов A.B., Кашин В.A. Налоговая политика и налоговое администрирование: учеб. пособие. М.: ИНФРА-М, 2013. 462 с.

11. Россия в цифрах: статистический ежегодник [Электронный ресурс] // Росстат: офиц.сайт. Электрон. дан. М., 2014. URL: http://www.gks.ru/bgd/ regl/b14_12/Main.htm (дата обращения: 10.10.2014).

12. Отчет о результатах контрольного мероприятия «Аудит эффективности деятельности Федеральной налоговой службы и ее территориальных органов в части администрирования доходов федерального бюджета и использования средств, выделенных из федерального бюджета на обеспечение деятельности налоговых органов, в соответствии с установленными Правительством Российской Федерации критериями за 2007 год и истекший период 2008 года» [Электронный ресурс] // Счетная палата: офиц. сайт. Электрон. дан. M., 2014. URL: http:// audit.gov.ru/activities/bulleten/?section=626 (дата обращения: 18.10.2014).

13. Основные направления налоговой политики в Российской Федерации на 2007-2009 гг. URL: http://newsruss.ru/doc/index.php/ Основные_направления_налоговой_политики_в_ Российской_Федерации_на_2007-2009_годы

14. Программа антикризисных мер Правительства Российской Федерации на 2009 год (утв. Правительством РФ 19 июня 2009 г.) [Электронный ресурс] // Гарант: информационноправовой портал. Электрон. дан. М., 2014. URL: http://www.garant.ru/ products/ipo/ prime/doc/ 12068944/ (дата обращения: 02.10.2014)

15. Основные направления налоговой политики в Российской Федерации на 2008-2010 гг. URL: http://minfin.ru/ common /img/ uploaded/library/ 2007/ 05/ taxpoltend.pdf

16. Основные направления налоговой политики на 2009 год и на плановый период 2010 и 2011 годов. URL: http://taxpravo.ru/novosti/statya-59565-osnovnyie_napravleniya_nalogovoy_ politiki_rf_na_2009-2011_goda

17. Налоговый кодекс Российской Федерации от 05.08.2000 №197-Ф3 (в ред. от 01.01.2014) [Электронный ресурс] // Гарант : информационно-правовой портал. Электрон. дан. M., 2014. URL: http://www. garant.ru (дата обращения: 19.09.2014).

18. Основные направления налоговой политики на 2010 год и на плановый период 2011 и 2012 годов. URL: / http://www.consultant.ru/document/cons_doc_LAW_88298/

19. Основные направления налоговой политики на 2011 год и на плановый период 2012 и 2013 годов. URL: http://www.consultant.ru/ document/cons_doc_LAW_105756/

20. Основныле направления налоговой политики на 2012 год и на плановый период 2013 и 2014 годов. URL: http://www.consultant.ru/ document/cons_doc_LAW_118742/

21. Основные направления налоговой политики на 2013 год и на плановый период 2014 и 2015 годов. URL: http://www.consultant.ru/document/cons_doc_LAW_129118/

22. Основные направления налоговой политики на $201 \overline{4}$ год и на плановый период 2015 и 2016 годов. URL: http://www.minfin.ru/common/ img/uploaded/library/2013/06/ONNP_2013-0605.pdf

23. Основные направления налоговой политики на 2015 год и на плановый период 2016 и 2017 годов. URL: http://www.fer.ru/pfmtap/files/Os_napr_nal_pol.pdf 
24. Бюджетное послание Президента России о бюджетной политике в 2012-2014 годах [Электронный ресурс] // Президент РФ: офиц. сайт. Электрон. дан. M., 2014. URL: http://www. kremlin.ru/acts/11779 (дата обращения: 21.11.2014).

25. Состояние и актуальные проблемы совершенствования законодательства в сфере науки и научно-технической деятельности: рекомендации парламентских слушаний от 26.11.2009 г. [Электронный ресурс] // Совет Федерации: офиц. сайт. Электрон. дан. М., 2014. URL: http://media. council.gov.ru/publications_sf/2009/11/item348.html (дата обращения: 12.10.2014).

26. Мурзов И.А. Технологическая модернизация и налоговая политика // Финансы и кредит. 2012. № 4. С. 27-34.

27. Данные по формам статистической налоговой отчетности [Электронный ресурс] // Федеральная налоговая служба: офиц. сайт. Электрон. дан. M., 2014. URL: http://www.nalog.ru/rn70 /related_activities/statistics_and_analytics/ (дата обращения: 24.11.2014)

28. Правительство готово пожертвовать самой успешной реформой $2000-\mathrm{x}$ - отказаться от плоской 13-процентной шкалы подоходного налога [Электронный ресурс] // Налоговый портал. Электрон. дан. M., 2014. URL: http://www.podatinet.net/2013070132156/stati/nalog-na-dohodyfizicheskih-lic-ndf1/pravitelstvo-gotovo-pojertvovat-samoi-uspeshnoi-reformoi-2000ah-a-otkazatsyaot-ploskoi-13aprocentnoi-shkaly-podohodnogo-naloga.html (дата обращения: 02.10.2014).

29. Абдуллаева Ш.Г., Сулейманова А.М. Анализ основных тенденций в российской налоговой политике // Государственное и муниципальное управление в XXI веке. 2012. №5. С. 42-46.

30. Поголецкий А.И. Налоговая политика ведущих зарубежных стран: современные аспекты // Финансы и кредит. 2012. № 13. С. 71-80.

Kuklina T.V. National Research Tomsk Polytechnic University, National research Tomsk State University (Tomsk, Russia). E-mail: tyarm@mail.ru

FISCAL POLICY AND IT'S ROLE IN THE SOCIO-ECONOMIC DEVELOPMENT OF RUSSIA.

Keywords: tax policy, social and economic development, tax code, elements of taxation, the tax burden, tax evasion, budget.

This article analyzes the effect of the direction of state tax policy on the socio-economic development of Russia from the period of 1991till the present years. The author defines the stages in the formation of public policy, allocated on the basis of the objectives and key challenges facing the Government of the country for 1991 to the present time. The author concludeskey areas of state tax policy relevant to the current state of socio-economic development of Russia.

\section{References}

1. AzarkinN.N., LevchenkoV.N., MartyshkinO.V. Istoriyapoliticheskihucheniy: vol.1 / N.N. Azarkin, V.N. Levechenko, O.V. Martyshkin.-M.:Jurist, 1996.-140 p.

2. Gobbs T. Leviafanilimaterija, forma ivlast' gosudarstvacerkovnogoigrazhdanskogo / T.Gobbs.M.:Mysl', 2001.-478 p.

3. Pushkareva V.M. Istoriyafinansovoymysliipolitikinalogov / V.M. Pushkareva.-M.: Finansyistatistika, 2008.-252 p.

4. Smit A. Issledovanie o prirodeiprichinahbogatstvanarodov.-M.:Soctcekizd., 1962. p.15

5. KejnsDzh.M. Obshhayateoriyazanyatosti, procentaideneg.-M.:Progress, 1992.-pp.25,27

6. Lyjah O.A., Grinkevich L.S. Regional'nayanalogovayapolitika: sushhnost', napravleniyasovershenstvovaniya /O.A. Lyah, L.S. Grinkevich. -Tomsk: Izd-vo NTL, 2010.- 240 p.

7. Borisov A.B. Bol'shojekonomicheskiyslovar' / A.B. Borisov.-M.: Knizhnyymir, 2007.-860 p.

8. Luk'yanova N.G. Upravlenienalogovoysistemoygosudarstva: sistematizaciyaponyatiynogoapparata // Finansovyy mir.-2002.-vol.1.-p.360

9. Chernik D.G. Nalogiinalogooblozhenie / D.G.Chernik.-M.:INFRA-M, 2001, 574 p.

10. Aronov A.V., Kashin V.A. Nalogovayapolitikainalogovoeadministrirovanie: uchebnoeposobie. INFRA-M, 2013. 462 p.

11. Rossiya v cifrah: statisticheskiyezhegodnik. Available at: http://www.gks.ru/bgd/regl/b14 12/Main.htm (accessed: 10.10.2014)

12. Otchet o rezul'tatahkontrol'nogomeropriyatiya «Audit effektivnostideyatel'nosti Federal' noynalogovoysluzhbyieeterritorial'nyhorganov v chastiadmini strirovaniyadohodovfederal'nogobjudz- 
hetaiispol'zovaniyasredstv, vydelenny hizfederal'nogobjudzhetanaobespecheniedeyatel'nostinalogovy horganov, v sootvetstvii s ustanovlennymiPravitel'stvom RossiyskojFederaciikriteriyamiza 2007 god iistekshiy period 2008 goda». Available at:: http://audit.gov.ru/activities/bulleten/?section=626 (accessed: 18.10 .2014$)$

13. Osnovnyenapravleniyanalogovoypolitiki v RossijskoyFederaciina 2007-2009 gg. Available at: http://newsruss.ru/doc/index.php/Osnovnye_napravlenija_nalogovoj_politiki_v_Rossijskoj_Federacii_ na_2007-2009_gody (accessed: 10.10.2014)

14. ProgrammaantikrizisnyhmerPravitel'stvaRossiyskoyFederaciina 2009 god (utv. Pravitel'stvom RF 19 iyunya 2009 g.) Available at:: http://www.garant.ru/products/ipo/prime/doc/12068944/ (accessed: 02.10.2014)

15. Osnovnyenapravleniyanalogovoypolitiki v RossiyskojFederacii na 2008 - 2010 gg. Available at: /http://minfin.ru/common/img/ uploaded/library/2007/ 05/taxpoltend.pdf (accessed: 12.10.2014)

16. Osnovnyenapravleniyanalogovoypolitikina 2009 god inaplanovyy period 2010 i 2011 godov. Available at: / http://taxpravo.ru/novosti/statya-59565-osnovnyie_napravleniya_nalogovoy politiki _rf_na_2009-2011_goda (accessed: 13.10.2014)

17. NalogovyyKodeksRossijskoyFederaciiot 05.08.2000 №197-FZ (v red. ot 01.01.2014). Available at: http://www. garant.ru (accessed: 19.09.2014)

18. Osnovnyenapravleniyanalogovoypolitikina 2010 god inaplanovyy period 2011 i 2012 godov. Available at:http://www.consultant.ru/document/cons_doc_LAW_88298 (accessed: 12.10.2014)

19. Osnovnyenapravleniyanalogovoypolitikina 2011 god inaplanovyy period 2012 i 2013 godov. Available at:http://www.consultant.ru/document/cons_doc_LAW_105756/ (accessed: 12.10.2014)

20. Osnovnyenapravleniyanalogovoypolitikina 2012 god inaplanovyy period 2013 i 2014 godov. Available at:http://www.consultant.ru/document/cons_doc_LAW_118742/ (accessed: 13.10.2014)

21. Osnovnyenapravleniyanalogovoypolitikina 2013 god inaplanovyy period 2014 i 2015 godov. Available at:http://www.consultant.ru/document/cons_doc_LAW_129118/(accessed: 14.10.2014)

22. Osnovnyenapravleniyanalogovoypolitikina 2014 god inaplanovyy period 2015 i 2016 godov. Available at:http://www.minfin.ru/common/img/uploaded/library/2013/06/ONNP_2013-06-05.pdf (accessed: 14.10.2014).

23. Osnovnyenapravleniyanalogovoypolitikina 2015 god inaplanovyy period 2016 i 2017 godov. Available at:http://www.fer.ru/pfmtap/files/Os_napr_nal_pol.pdf (accessed: 14.10.2014)

24. BudzhetnoeposlaniePrezidentaRossii o budzhetnoypolitike v 2012-2014 godah. Available at: http://www.kremlin.ru/acts/11779 (accessed: 21.11.2014)

25. Sostoyanieiaktual'nyeproblemysovershenstvovaniyazakonodatel'stva $\mathrm{v}$ sferenaukiinauchnotehnicheskoydeyatel'nosti: rekomendaciiparlamentskihslushanijot $26.11 .2009 \mathrm{~g}$. Available at:http:// media.council.gov.ru/publications_sf/2009/11/item348.html (accessed: 12.10.2014)

26. Murzov I.A. Tehnologicheskayamodernizaciyainalogovayapolitika // Finansyikredit. Vol.4. 2012 p. $27-34$

27. Dannyepoformamstatisticheskoynalogovoyotchetnosti. Available at:http://www.nalog.ru/rn70 related_activities/statistics_and_analytics/ (accessed: 24.11.2014)

28. Pravitel'stvogotovopozhertvovat' samojuspeshnoyreformoy 2000-h - otkazat'sjaotploskoj 13procentnoj shkalypodohodnogonaloga. Available at:http:// www.podatinet.net/ 2013070132156/stati/ nalog-na-dohody-fizicheskih-lic-ndfl/pravitelstvo-gotovo-pojertvovat-samoi-uspeshnoi-reformoi-2000 ah- a-otkazatsya-ot-ploskoi-13aprocentnoi-shkaly-podohodnogo-naloga.html (accessed: 02.10.2014)

29. AbdullaevaSh.G., Sulejmanova A.M. Analizosnovnyhtendencij v rossijskoynalogovoypolitike // Gosudarstvennoeimunicipal'noeupravlenie v XXI veke. 2012. Vol.5. p.42-46

30. Pogoleckiy A.I. Nalogovayapolitikavedushhihzarubezhnyhstran: sovremennyeaspekty // Finansyikredit. Vol.13. 2012, p.71-80. 